\title{
To Moscow with Love: Partial Reconstruction of Vygotsky's Trip to London
}

\author{
René van der Veer • Ekaterina Zavershneva
}

Published online: 31 May 2011

(C) The Author(s) 2011. This article is published with open access at Springerlink.com

\begin{abstract}
The Russian psychologist Lev Vygotsky (1896-1934) left the Soviet Union only once to attend a conference on the education of the deaf in London. So far almost nothing was known about this trip, which took place in a period when Vygotsky was still completely unknown as a psychologist, both inside his own country and abroad. Making use of a newly discovered notebook, it proved possible to partially reconstruct Vygotsky's journey and stay in London. Vygotsky's very personal remarks show him to have been a very sensitive and spirited man, who was prey to strong emotions during the conference and afterwards. Rather surprisingly, Vygotsky's own paper about the education of the deaf was never presented during the conference and the stay in London appears to have had a limited value for his own scientific development.
\end{abstract}

Keywords Vygotsky $\cdot$ Deafness $\cdot$ Biography $\cdot$ History $\cdot$ Defectology

London conference

\section{Introduction}

Vygotsky's one and only trip to the West took place in the Summer of 1925. His primary goal was to represent the Soviet Union at the 8th International Conference on the Education of the Deaf, which took place in London from Monday, July 20, to Friday, July 24. Several months earlier the Soviet government had received an invitation from the British government to send a delegate to this conference and in the highest ranks of the Ministry of Education it had been decided to appoint Vygotsky (Vygodskaya and Lifanova 1996, p. 84). In April, Vygotsky received a

R. van der Veer $(\bowtie)$

Department of Education, Leiden University, PO BOX 9555, Leiden, The Netherlands

e-mail: veer@fsw.leidenuniv.nl

E. Zavershneva

Moscow, Russia

照 Springer 
letter, signed by the Minister of Education Lunacharsky himself, with detailed instructions as to how to behave and which positions to defend in far-away England (Van der Veer and Valsiner 1991, pp. 45-6).

At the time, Vygotsky was a beginning specialist in the field of what was called 'defectology', the branch of science concerned with persons with handicaps such as blindness, deafness, or mental retardation. In 1924, he had been appointed Head of the Bureau for the Education of Physically and Mentally Disabled Children, a position that he combined with various other appointments, including one at the Psychological Institute of Moscow University. Apart from an edited volume (Vygotsky 1924a, b, c), Vygotsky had published virtually nothing in the field of defectology and it would take several years before he became acknowledged as an authority in that field in the Soviet Union. In fact, by the end of 1925 Vygotsky was the author of very few and mostly very brief psychological publications (Vygotsky 1924a, b, c, 1925a, b, c, d, e, f). The established Russian experts in the field of the education of blind and deaf children were such persons as Natalia Rau and Ivan Golosov in Moscow, Ivan Sokoloyansky in Kharkov, and Aleksandr Sherbina in Priluki, and it remains somewhat of a mystery why the young Vygotsky was chosen to represent his country abroad. Outside his home country, Vygotsky was, of course, completely unknown in any quality.

The position that Vygotsky defended in his paper for the congress was that it the secondary, social effects of a handicap that are most important and that it is essential to engage the children in meaningful social activities. The concrete ideas as to how to realize this approach were taken from Rau, Golosov, Sokoloyanski, and Malisch to whom Vygotsky extensively referred (Meshcheryakov 1974; Van der Veer and Valsiner 1991; Vygotsky 1925f).

Before he turned to defectology and psychology, Vygotsky worked as a literary critic and organizer of cultural events in his hometown Gomel. In that quality, he published dozens of reviews in journals and newspapers. The experience he gained in writing these reviews was used in his doctoral dissertation, The psychology of art, which he planned to defend after the London conference. However, Vygotsky had suffered from tuberculosis since at least 1920 and due to a relapse of his illness after his trip to London, he was unable to defend his thesis in public. In October 1925, Vygotsky was formally exempted from this duty (Van der Veer and Valsiner 1991, p. 46). With hindsight, it is obvious that for Vygotsky the years 1924 and 1925 formed a period of transition from the world of literature and theater to the academic world. It was also a transition from the psychology of art to developmental and general psychology and it comes as no surprise that Vygotsky during his stay in London - just like he had done in his dissertation — now and then thought about the effects of works of art on the human mind.

So far, little was known about the details of Vygotsky's trip. It was speculated that Vygotsky on his way to and from London visited colleagues in Germany, Holland, and France, but no one was able to recover which institutes Vygotsky visited, with whom he discussed research, whether he held or attended lectures, and so on (Van der Veer and Valsiner 1991). Research in schools and institutions for the deafmute in various countries yielded no results. About the only trace that was left of Vygotsky's actual stay in London was the text of his conference paper and a few photographs from the conference proceedings where he can be seen amidst the other delegates. 
The proceedings themselves, however, have become quite rare and are difficult to obtain (Brill 1984; International Conference 1925).

\section{The Notebook}

Fortunately, quite recently, one of Vygotsky's notebooks, dealing directly with this journey, was discovered by the second author in the Vygodsky family archives. It is a truly unique notebook in that it not only enables us to partially reconstruct Vygotsky's foreign trip but also provides an insight into his state of mind. Unlike other notebooks that have been found or published, this one is filled with very personal remarks, which reveal unexpected tribulations and trepidations. Very characteristic is that the notebook begins with part of a poem written in the hand of Roza Noevna Smekhova, Vygotsky's wife since 1924, and dated June 16, 1921. The text is copied from a poem from Anna Akhmatova's second volume of poetry The Rosary, published in 1914. A prose translation would run something like: "Never mind that you are rude and ill-natured / Never mind that you love others / Before me I have the golden lectern / And with me my grey-eyed fiancée" (cf. Akhmatova 1977, p. 83). This choice of a text fragment is remarkable and it suggests that the young couple's engagement was not without its tensions. As we shall see, Vygotsky's further remarks in the notebook do nothing to take away that suggestion.

The notebook itself is in a poor condition, the notes are partially written in pencil, Vygotsky's handwriting is not altogether easy, and the frequent use of abbreviations makes the task of deciphering the notebook still more difficult. Nevertheless, we believe we have succeeded in reading and understanding the notebook to a sufficient extent. Apart from the text presented here, the notebook contains a considerable number of names, addresses, and telephone numbers, primarily from people living in London or Berlin. Interesting as they are, they will be ignored here as we have no means to establish whether Vygotsky contacted or visited these persons.

As noted before, the notebook contains numerous abbreviations that cannot be deciphered with certainty. Our interpretation of these abbreviations and other insertions will be given in square brackets. For example, the Russian abbreviation Г. Я л. т. will be rendered as G[okha] I 1[ove] y[ou], Gokha being the endearing name for Vygotsky's wife Roza Smekhova. Words or letters that are difficult to decipher are given in angle brackets. Words or phrases written in another language (e.g. French, English, or Latin) are italicized. Punctuation marks, question marks, and exclamation marks have been supplied when required, unless this would imply the choice for one of several possible interpretations. Also, we corrected incorrectly spelled foreign names or words. The chronology of the entries does not follow the page order and has to be inferred from references to events, names of the day, and so on. Two small fragments that could not be reliably dated have been omitted.

In the continuation, we will take a chronological approach, describing Vygotsky's journey and his stay in London and interspersing this with texts from his notebook to the extent that these were still legible. The proceedings will be used to reconstruct the daily course of events during the London conference. The notebook will add Vygotsky's personal reflections before, during, and after the conference. In 
presenting these notes, we believe we can shed some light on Vygotsky's complex personality and on an early and little known part of his scientific career.

\section{Traveling from Moscow to London}

On June 27, Vygotsky wrote a letter from Moscow to his Russian colleague in Priluki, the specialist in the psychology of the blind, and himself a blind person, Aleksandr M. Sherbina, in which he announced that he would be leaving for London "in a week". Apparently, he left Moscow somewhat later, on July 7, probably by steam train from Belorusskiy railway station (Rückriem 2008, p. 30). The distance from Moscow to Berlin is some 1600 kilometers and present-day trains still take more than $24 \mathrm{~h}$ to cover it. This makes us believe that Vygotsky arrived somewhere around July 8 or 9 in Berlin, where he would stay for more than a week.

So far, the evidence about Vygotsky's stay in Berlin is still scanty and in this article we will refrain from discussing it and concentrate on the rest of his European trip. But, of course, it is not overly risky to assume that Vygotsky visited the Institute of Psychology and met Gestalt psychologists such as Wolfgang Köhler, Kurt Lewin, Max Wertheimer and several of their Russian PhD students, among them Gita Birenbaum, Tamara Dembo, Maria Ovsiankina, and Blyuma Zeigarnik. With many of these persons Vygotsky would remain in contact in the subsequent years (Van der Veer, 2000). Vygotsky may have met his collaborator Luria as well, who in July was traveling with his father through Germany (Khomskaya 1992, p. 24). Certain is that one of Vygotsky's most well-known photographs was taken in Berlin (Vygodskaya and Lifanova 1996, p. 85).

Quite likely, Vygotsky caught the night train to leave Berlin at Thursday, July 17. What we know for sure is that early in the morning of Friday, July 18, Vygotsky arrived at Bentheim railway station, near the German-Dutch border. To his dismay, he had to wait for several hours for the locomotives to be changed. His passport was repeatedly checked, as it would be in Oldenzaal railway station in Holland somewhat later. Vygotsky then traveled further through the Netherlands in some 4-5 h and took a steamship in the early afternoon. At the time, trains from Berlin went to Vlissingen (Flushing), a small harbor in the south of the Netherlands where ferries departed for England. The ferry was exploited by the Stoomvaart Maatschappij Zeeland (Steamship Company Sealand). Boat trains went directly to the ferry and for decades this route formed the fastest connection between Berlin and London. The ferry also served as the main mail carrier from and to the UK. After World War II, the line changed into a connection between Hook of Holland (Hoek van Holland) and Harwich (Cf. Wikipedia: Stoomvaart Maatschappij Zeeland, http://nl.wikipedia. org/wiki/Stoomvaart_Maatschappij_Zeeland).

While in the train and on the ferry Vygotsky noted the following:

7 a.m. We are standing in Holland for $2 \mathrm{~h}$. I am inexpressibly lonely; it is hard and joyous at the same time. G[okha] I 1[ove] y[ou]. Instead of air, they have some sort of milky whitish steam here. It is warm, sunny. They have chubby, kind, white, round faces-especially the women. They just checked my passport for the hundredth time. These medieval regulations - are they theirs or 
others'? The astonishing material comfort [and] the military conditions create a strange contradiction. G[okha] I 1[ove] y[ou]. Be faithful to me. My G<i $>$ ta]. In Berlin I was thinking of you all the time. I am convinced that enormous ordeals lie ahead for us (Rus[sia]-Europe) — will you be happy and joyous? My darling. My light. In a foreign country, in the fresh air (an airplane ${ }^{1}$ ) at sea-you feel a strange aloofness of everything. A reconsideration of your whole life, a revision of the soul. Suddenly you look at your whole life from aside, as in the minute of death. How excruciating! My words in this unforgettable journey-I myself set the rules of the game. The unforgettable Berlin is like a sign of my courage. I became more cour $<$ ageous $>$ (again the passport-Oldenzaalmemorize!!!) only after this bleak, excruciating and wonderful day in B[erlin]. In my destiny, this is the sign of future enormous ordeals. Am I afraid? Of course, I am afraid, I feel terror, but keep it in check. I still have my strength and power. Let be. Gokha. $<\mathrm{Gi}$. $>$ I am with you.

2. 50 p. m. The ship just left from Vliss $<$ ingen $>$. Sea. Fog. I $<>$ G.

2. 55 p. m. The shores disappeared. Before the eye and in the soul [is] the same.

3. $30 \mathrm{p}$. m. As is known, in medicine there are allopaths and homeopaths, of the latter there are very few left. I perceive Europe homeopathically, i.e., so that it leaves no<traces $>$ in the organism, but the homeopaths say that the minimal doses are the strongest. If $<\mathrm{G}>$ would watch these enormous $<$ lines $>$ of the sea with me - this would straighten out our love (again homeopathy - the hope for a tiny fragment).

5. 25 p. m. A very strong wind. The sun. A rainbow. The enormous sea. Delight. All my sorrow and my fear sink in this enormous [space]. The white crests of the waves. [The boat is] rolling. Infinity is with me. G[okha] y[ou] a [re] f[or] e[ver] w[ith] m[e].

These first entries about Vygotsky's trip by train through Holland and his sailing to England are very characteristic of the notebook as a whole. Vygotsky mixed astute observations of his environment with very personal remarks about his state of mind, his feelings for his wife and his 2 months old daughter Gita and the calling he felt. The frequent abbreviated putative love declarations remind us of a passage in chapter 7 of his Thinking and Speech, where Vygotsky mentioned that the heroes Kitty and Levin in Tolstoy's novel Anna Karenina communicated in a similar way, i.e., by just writing down the first letters of words. Supposedly, because they knew each other's thoughts so well, they nevertheless understood the abbreviations effortlessly. With others, Vygotsky believed this fragment to be based on an episode in Tolstoy's own life, but subsequent biographers have called this into doubt (e.g., Wilson 1988, p. 194). At the time, Vygotsky had been married for about a year and his first child Gita was only several months old. Yet his notebook is filled with exclamations that seem to reflect a basic insecurity about his marital relationship. It is unclear whether Vygotsky's feverish and at times exalted remarks were rooted in

\footnotetext{
${ }^{1}$ Presumably, Vygotsky saw an airplane in the sky while sailing. This was still an unusual sight in the 1920s and hence noteworthy.
} 
real events or somehow reflected his very bad health with possibly resulting frequent mood swings.

\section{The Conference}

Quite likely, somewhere in the early morning of July 19, Vygotsky arrived in the harbour of Folkestone, which was the destination of the ferry in 1925 (Wikipedia: Stoomvaart Maatschappij Zeeland, http://nl.wikipedia.org/wiki/Stoomvaart_Maatschappij_ Zeeland). He then must have traveled by train to London. Unfortunately, there are no entries in his diary that can be reliably connected with this or the next day of his stay in London. It is possible that he was lodged at the Osborne Hotel at 2, Gordon Place, not far from Hyde Park - stationary of this hotel with Vygotsky's handwriting was found in the Vygodsky family archives - , and may have rested there or talked with some of the approximately 500 colleagues who attended the conference. The conference itself was held at the London Day Training College (LDCT) at Southampton Row and Lord Charnwood, president of the National College of Teachers of the Deaf, chaired several of the sections (Brill 1984; International Conference, p. 17).

The London Day Training College was founded in 1902 and served the education of teachers at primary and secondary schools. The students were mostly young women who were required to undertake both academic courses and do practical teaching in local schools. When Vygotsky visited the College, its principal was professor Sir Percy Nunn. Nunn hired well-known psychologists such as Susan Isaacs and Cyril Burt for part of the teaching (cf. website Institute of Education, http://www.ioe.ac.uk/about/761.html). During the conference, presentations were given in the large lecture theatre on the ground floor. The delegates heard 17 papers and also could watch about 20 demonstrations of what were then considered useful skills and activities for handicapped children in the Exhibition Hall. These activities were introduced and guided by a teacher and varied from "practical woodwork" via "lacemaking" to "drill and dancing" (Brill 1984, p. 80; International Conference, pp. 213-218).

Judging by the proceedings, the conference was a rather formal event: Honorable Lords and Ladies received the delegates at the opening reception and farewell dinner and presided over most of the scientific sessions. Invariably, someone would stand up at the end of a session and move a "vote of thanks" to the Hon. Lord or Lady for his or her amiable presence, which then would be seconded by another delegate and carried with acclamation. One may surmise that these were not exactly the surroundings where a young communist would feel very much at ease.

In her biography, Vygotsky's oldest daughter, the late Gita Lvovna Vygodkaya, has written that during the conference Vygotsky interacted mostly with the Czecho-Slovakian delegation, with Schorsch from Berlin, and with Sangu from Yokohama (Vygodskaya and Lifanova 1996, pp. 88-89). If true, that would be a rather mixed company. Ernst Schorsch (1869-1943) was director of the City Institution for the Deaf in Berlin, chairman of the League of German Teachers of the Deaf, and author of various books. Much later, when the Nazis seized power in Germany, he was dismissed, because he refused to raise the Nazi Party flag over his 
school (Muhs 2002, p. 88-89). The Czecho-Slovakians included F. M.D. Kriz, V. Parma, and M. Bednarik. The latter was superintendent of the Institution for the Deaf at Plzen and president of the Society of Teachers of the Deaf in Czecho-Slovakia at Prague. He did not give a talk during the conference. Finally, professor Makoto Sangu (1892-1976) was something of an odd figure at the conference. He seems to have been a poet and a specialist in English literature with no knowledge at all about the education of the deaf (personal communication, professor Takashi Murakami, Chukyo University, April 2010). In his farewell words, he confessed that "for some reason-I know not what - the Japanese authorities could not send a specialist to this conference, and I am very sorry that I, being no specialist, have not been able to appreciate this conference as much as a specialist would". The paper under his name was not read during the conference but published in the proceedings (International Conference, pp. 212/242-246).

\section{The Conference's First Day}

The first entries in Vygotsky's notebook that can be reliably connected to the conference activities are those that refer to its first day: Monday, July 20. Lord Charnwood opened the first session at 10. 30 a.m. in Kingsway Hall —a Methodist church building that subsequently became famous for its acoustic properties - and "extended a hearty welcome to all delegates" (International Conference, p. 17). Before Charnwood arrived, Vygotsky had jotted down his first observations, presumably while sitting and waiting in the hall:

10. 15. a.m. In $15 \mathrm{~min}$ the conference will be opened. I was presented to the Presid[ent] and I was moved from the 4th to the 1st row. I am alone. Slightly cold. Calm. I am a stranger to myself - in the mirror and in feeling, but your name G. is with me and I am calm. Not without reason the ancients believed in the name as a reality (res) — a genius. In your name, G[okha] m[y] b[eloved] $\mathrm{w}[\mathrm{ife}]$. Let be.

Apparently, Vygotsky was introduced to Lord Charnwood and then, being a foreign guest and the formal representative of his country, moved to the first row. Vygotsky's comments about being a stranger to himself are self-evident. Obviously, he felt ill at ease in a strange environment and wearing cloths he was not used to (see below). By thinking of his wife he managed the resulting tension. After Lord Charnwood's words of welcome, Lord Percy, Minister of Education, took the word and expressed his interest in the education of the deaf. Schorsch from Berlin briefly underlined the importance of the conference and the need to make progress in the education of the deaf. On the initiative of Lady Lawrence, and seconded by J. Brown, chairman of the National College of Teachers of the Deaf, the delegates then carried a vote of thanks with acclamation to Lord Percy for his presence. After that, the standing orders were read and accepted unanimously and the meeting was closed. The delegates moved to the London Day Training College, where they gathered in the Exhibition Hall to admire, again after several speeches, the display of work from deaf children from various institutions. 
The second session began at 2.00 p.m. but slightly earlier Vygotsky entered another striking observation in his notebook.

1: 50 p.m. $<$ Break - we drink tea $>$. Anxiety, what is the matter with you G., why are you depressed? I sit on the terrace of County Hall on the very Thames. Just opposite the Parliament and the Westminster Abbey. The fog thickens, like a veil. Calm. Some minutes it is slightly absurd, other minutes it is as if I have been for 5 years in London and in this company. You cannot think of a loneliness that is more severe and awful. How is Gi, how is G? Is she with me? $<$ Frailty $>$. If only we could tear out minutes of our live. Verweile doch, not because it would be beautiful, but because it would be bliss. $<$ Malisch $>$ died 2 weeks ago. My journey is astounding and its purport is much more important and larger than just its work aspect. Success, good fortune, $\mathrm{I}<$ recover/depart $><\ldots>$ and more than I see myself: these minutes will illuminate my whole life. G[okha] y[ou] $\mathrm{a}[\mathrm{re}] \mathrm{w}[\mathrm{ith}] \mathrm{m}[\mathrm{e}]$.

The sudden reference to his wife being depressed is surprising as it was not mentioned in the entry made several hours earlier. The worries about their relationship continue throughout the notebook and may seem odd in a couple that has been married for just 1 year and with a baby of just a few months old. However, the references to Shakespeare's Hamlet ("Frailty, thy name is woman") and Goethe's Faust ("Verweile doch, du bist so schön", English: "Tarry a while! You are so fair!) seem to leave us no other interpretation (Wikipedia: Faust: The First Part of the Tragedy, http://en. wikipedia.org/wiki/Goethe\%27s_Faust\#The_First_Part_of_the_Tragedy; Goethe 1975, p. 57). Konstantin Malisch (1860-1925) was an Austrian specialist in the education of the deaf to whom Vygotsky referred in his conference paper. Malisch died on July 11, 1925 (Van der Veer and Valsiner 1994), so that Vygotsky's "2 weeks ago" was more or less accurate.

The afternoon session, chaired by Lord Gorell, consisted of talks by A. Eichholz and A.J. Story, both of England, and was followed by a brief discussion. A resolution to appoint an International Committee to collate the various views and developments in different countries was supported and accepted (International Conference, p. 56). That finished the scientific part of that day but in the evening the delegates were received by the Hon. Lady Lawrence at the County Hall. With more than 400 others Vygotsky attended this reception listening to music by the Witan Orchestra, watching "educational lantern slides" and inspecting the educational library (International Conference, p. 219). A photograph taken on the terrace before the reception shows Vygotsky amidst the other delegates in a black suit, white shirt with stiff collar, and bow tie.

\section{The Second Day}

The second day, July 21, was opened at 9.30 a.m. by the Roman-Catholic Cardinal Bourne who thought that "anyone who professed the Christian faith must always have a special interest in those afflicted by deafness. They had made a special appeal to Our Divine Master when He trod this earth, and anything one did for them must 
of necessity be inspired by thought of the sympathy He Himself had shown them" (International Conference, p. 57). Then A. Hansen of Denmark read a paper about the classification of deaf children claiming, among other things, that the Danish system was both "the oldest and the most scientific" one (International Conference, p. 59). Vygotsky seemed neither convinced nor too interested:

10.20 a.m. The cardinal opened the meeting. Not very approving of nonChristians. $<$ Hansen $>$ is reading. Loss of strength. I am tired. Indifference, almost despair. My trip yesterday revealed to me its main contradiction. I am extremely tense (the language, the responsibilities, the suit, the foreign countries), on the other hand-I am outside time and space and free of everything as never before (aloof). The former pushes aside everything that yesterday was still dear to me and excited me (the flat and other things). The latter is a huge entrance to the basic undercurrents of life. A journey is a «trial of oneself $\gg$. This is life, shattered in moments $(<\mathrm{very}\rangle)$, but also sub specie aeternitatis. In essence, Russia is the first country in the world. The Revolution is our supreme cause. In this room only 1 person knows the secret of the genuine education of the deafmutes. And that person is me. Not because I am more educated than the others, but [because] I was sent by Russia and I speak on behalf of the Revolution. My Gokha. Be faithful to me. My heart is restless, there is some warm dampness outside and in my soul.

11 o'clock the embassy. An enormous waiting-room. Gi probably feeds for the second time today. How did it go tonight? G[okha] y[ou] a[re] a[lways] w[ith] $\mathrm{m}[\mathrm{e}]$.

The passage beginning with "The Revolution is our supreme cause" and ending with "I speak on behalf of the Revolution" is very revealing. We already knew that Vygotsky was a convinced Marxist, who did not want to create a Marxist psychology by "picking out a couple of citations". Instead, he wished "to learn from Marx's whole method how to build a science, how to approach the investigation of the mind" (Vygotsky 1926/1997, p. 331). We also knew that Vygotsky was very actively participating in various social activities in the new communist society, giving evening courses to metal workers, and so on. (Valsiner and Van der Veer 2000, pp. 330-332). It seemed safe, then, to assume that Vygotsky identified with the emancipating pathos of the October Revolution (Van der Veer 2007, p. 19). Moreover, at times - in private correspondence, for example - one sensed that Vygotsky, in a semi-religious way, felt himself and his group to be on the road towards the creation of a truly new psychology (Van der Veer, 2008, pp. 189190). The present statement in his personal notebook, however, is the first statement that quite literally proves that Vygotsky identified with the Revolution and felt chosen to defend its higher truth. Here we have, then, a curious mixture of exalted feelings of being chosen to accomplish great things in science and feelings of utter loneliness, tension, and doubts.

Hansen's talk was followed by a presentation by G. Ferreri from Milan, a brief discussion, and the acceptance of another resolution. The presentations were 
continued in the fourth session of the congress, chaired by the Duchess of Atholl, and which began at 2 p.m. Miss M. Hare from England and E. Aurell from Sweden gave talks about the oral method in teaching speech to deaf children. These were followed by a lively debate and the award of the Braidwood Medal to W. Cockersole of the Royal Deaf School, Derby, for an essay published the year before (International Conference, p. 91). That ended the formal part of the second day.

Some 250 of the delegates now took "motor-coaches" to Oak Lodge Residential School for Elder Deaf Girls and the Jews' Deaf and Dumb Home (International Conference, p. 210). Oak Lodge School opened in 1905 as a secondary oral school for girls aged 11-16. It was and still is located on 101 Nightingale Lane. In the 1920 s, there were some 50, mostly poor, girls who were being prepared to become servants and domestic workers (cf. website Oak Lodge School, http://www.oaklodge. wandsworth.sch.uk/home/history/history.html). At that time, the school was separated from the neighbors, the Jews' Deaf and Dumb Home, by a high wall. No contact whatsoever between the schools existed. The Jews' Deaf and Dumb Home was an oral school founded in 1865 . The children learned Hebrew so that they could read prayers and part of the book of Genesis. The school closed in 1965 for lack of pupils (cf. website Jewish Deaf Community Center, http://www.jdcc.org/novemberdecember-1995-issue?layout=blog).

The delegates then moved on to the Anerley Resident School for Deaf Boys. Anerley was a school for deaf boys aged 13-16 near Chrystal Palace. It was closed in 1957 and its pupils moved to Oak Lodge School, which then became a day school for boys and girls. At all three schools, Vygotsky and his colleagues saw classes at work and displays of physical exercises.

\section{The Third Day}

On Wednesday, July 22, the delegates took a special train to the Royal School for the Deaf in Margate at the coast of the North Sea. They left from Victoria Station at 8.50 a.m. and arrived about $1 \mathrm{~h}$ and $45 \mathrm{~min}$ later in Margate (International Conference, p. 95). The Royal School for the Deaf was the oldest and largest institution for deaf and mentally and physically defective children in the UK (Brill 1984). It was founded in 1792 as the London Asylum for the Education of the Deaf and Dumb Children of the Poor and opened a branch in the seaside resort Margate in 1876 (cf. Wikipedia: History of Margate, http://en.wikipedia.org/wiki/History_of_ Margate\#Royal_School_for_Deaf_Children). Located on a beautiful site in the center of Margate, the school offered a special program to the foreign guests. The delegates were welcomed by the chairman of the committee of the school, G.J. Allen, and the mayor of Margate, T.D. Wood (International Conference, pp. 95/220). They then listened to Dr. Percival Hall, president of Gallaudet College in Washington, who talked about higher education of the deaf in the United States. Hall outlined the history of Gallaudet College and its contemporary organization.

Subsequently, the guests were shown the school buildings and enjoyed a lunch. Lord Aldenham presided a prize-giving ceremony (a distribution of prizes to the 
pupils by the Hon. Mrs. G. Gibbs) and various persons seized the occasion to speak memorable words and praise the school. The deaf-mute students of the school then performed Michael W. Balfe's opera The Bohemian Girl. According to the proceedings "the performance... in a sunny pastoral setting was very effective, the coloured costumes being enhanced by the freshness of the verdant scenery" (International Conference, p. 104). Vygotsky had his own ideas about the performance and Margate:

5 p.m. I am lying on the playing field. 250 deafmute children perform $\ll$ The Bohemian girl». The lords with golden chains. Tea. Walked around, saw the sea-enormous and amorphous, the coast is awful (a health resort). I shall, of course, never in my life be in Margate again. So be it. So much the easier. The time has passed when I thought that this depreciates everything. Gokha, you alone I need until death. And] m[aybe] Gi[ta].

\section{The Fourth Day}

Thursday, July 23, saw presentations by M.A. Goldstein from St. Louis, USA and, $\mathrm{Ph}$. Michels from Budapest, Hungary during the morning session and papers by $\mathrm{O}$. Taube from Schleswig-Friedrichsberg, Germany, and R.G. Woltjer from Groningen, The Netherlands, during the afternoon session, but Vygotsky made no entries in his notebook about this day. It is certain, though, that, at the close of the afternoon session he joined other delegates in a trip by bus to Buckinghamshire to see the School for the Defective Deaf at "Rayners". Rayners was a large Victorian house in Penn surrounded by 22 acres of parkland and formerly owned by Sir Philip Rose. The school changed names several times and is now Penn School for children with communication problems associated with speech and language. In 1925, the international delegates were entertained to tea, and, after a drill display by the whole school, including the deaf-blind, visited the workshops, house and grounds (International Conference, p. 220). A photograph taken at what was called the "Garden Party" shows "L. Wygotski" with some 40 other foreign guests.

\section{The Fifth Day}

The final day of the congress, Friday, July 24, saw speeches by A.E. Pope from New Jersey, W.M. Nelson from Manchester, and B.P. Jones from the London County Council during the morning session, which began at 9.30 a.m. Vygotsky was not amused and as usual was brooding over his private affairs:

10. 50 a.m. The last day of the congress. A boring talk. A humid, incomparably mild morning and a very special grief. And I am waiting for something all the time, am looking for some words, for at bottom I no longer want anything. I myself set the rules of the game. Gokha. Gi. Your names are with me. 
At 2 p.m. the congress ended with a closing session with speeches by E. Ayliffe, president of the British Deaf and Dumb Association, M.B. Thollon from Paris, and a proposal for a World Union by M. Sluizer from Amsterdam. Vygotsky noted:

3: 40 p.m. The last session is taking place. Tonight is the farewell dinner and everything will be over. So be it.

The speeches were followed by words of thanks from the foreign delegates. According to the proceedings, "mr. Vigotsky" spoke the following words:

I salute the conference in the name of the Socialist Soviet Republics of Russia and in the name of the Commissioners of the Russian People for Public Education. I thank the committee for the reception in London, and I trust that the discussions of the conference will have real success. (International Congress, p. 211)

Again, Vygotsky noted his impressions in his notebook:

4: 32 p.m. I said the final words au nom etc. Ahead is an enormous freedom, emptiness, solitude and melancholy. I'll wait for you. G. My wife.

Thus, on the congress' final day as well Vygotsky mixed observations of the congress affairs with remarks about his innermost feelings. It seems as if throughout the conference for whatever reason he was constantly analyzing his own state of mind and, moreover, registering them in his notebook. The final day was concluded by a farewell dinner and dance at the Hotel Victoria, Northumberland Avenue. The guests were received by Lord and Lady Charnwood. It is unknown whether Vygotsky was able to dance.

The reader will have noticed that in the account of the scientific sessions Vygotsky's own paper, entitled Principles of social education for deaf and dumb children in Russia, was not mentioned. Nor did Vygotsky make mention of the presentation of his paper in his notebook. The explanation is quite simple: Vygotsky never presented his views to the other delegates. With seven other texts, his text belonged to the "papers submitted for incorporation in the report", which were added to the proceedings of the congress under the heading Addendum (International Conference, pp. vi/ 221). Whether he would have liked to read his paper in public and, indeed, whether his paper was ready when the conference began, we do not know. Parallel sessions did not exist and possibly not all of the submitted papers could be presented. The proceedings themselves, although dated 1925, seem to have been published 1 year later and it is entirely possible that papers were added after the conference. If we take into account that Vygotsky did not take part in the discussions at the end of the scientific sessions, did not read his paper, and only spoke a few sentences in his farewell words, it can be assumed that his presence at the London conference went by virtually unnoticed. It is remarkable that the Soviet government spent so much money on a visit that to the modern eye seems so utterly "unproductive".

\section{Sightseeing}

Rather surprisingly, after the conference Vygotsky did not leave the United Kingdom at once. He might have taken one of the daily ferries to Vlissingen the next day, but 
instead choose to stay in London for another 11 days. We know very little of his activities during that period. It is tempting to imagine Vygotsky in the Reading Room of the British Library, some 75 years after his source of inspiration, Karl Marx. Unfortunately, we have no means to confirm this speculation. We can also assume that he met several of the persons whose London addresses were in his notebook but we cannot take it for granted. What we know for certain, on the other hand, is that Vygotsky spent part of his remaining days in London sightseeing. Thus, on Tuesday, July 28, Vygotsky visited the National Gallery and was deeply moved by part of the collection.

3. 20 p.m. The National Gallery: no Rafael, da Vinci or Michelangelo, no French and no Dutch, even no Dührer. The Spaniards Greco, Goya, Velasquez. I am sitting before Goya's portrait and Greco's pink-black Christ. My soul is full of flashes of burnt out passions. In my mind is nothing - or an appraisal. I am searching confirmation of the theory on the portrait and the overcoming of the body.

This is a particular dense passage. It seems that Vygotsky was at first highly moved by the paintings and then - after he had calmed down somewhat (hence, the 'burnt out passions') - attempted to analyze the way the paintings produced this effect on his mind (hence, the 'appraisal'). Presumably, then, he was seeking to interpret the artistic effect of Goya's portrait (either Doña Isabel de Porcel, or Don Andrés del Peral, or The Duke of Wellington) and Greco's The Agony in the Garden of Gethsemane in light of his own theory of art (cf. website National Gallery, http://nationalgallery.org.uk/paintings/collection-overview/). The theme of the "overcoming the body" is akin to the Spinozian theme of mastering the passions and gaining control over one's behavior that we know from other writings by Vygotsky (cf. Van der Veer 2007).

The next day Vygotsky continued his tourist activities and visited the British Museum. The many archeological findings from Egypt left a particular deep impression on the Russian visitor:

3 p.m. British Museum. In the morning there was a telegram. How far away I am each minute something $<\ldots>$ with me, my Roza, that all this $\mathrm{I}<\ldots>$ alone, and not together with you. Who once saw Egyptian skeletons and mummies (one with hair) in a simple chest made of planks with cement, already views the world in another way. What I would $<\ldots>$ with you! Today I am anxious and in $<$ pain $>$ all day. It seems to me that $\mathrm{I}$ am on the point of $<\ldots>$ on this terrible $<\ldots>$

Two days later, on Friday, July 31, we find Vygotsky sitting in a café on Piccadilly Circus.

9. 35 p.m. Lion's Tea Piccadilly. Tea. Inexpressibly sad. Why is G. not happy? $<$ For $>$ you believed in your happiness. Oh, how I would love to see you happy! More than anything I want that. I am already almost free of personal longings. I saw the planks and the Egyptian putty, my brothers. Oh, how we must despise and respect life at the same time in order to live. The main thing 
is to be above life, to deal with it slightly condescendingly (Chekhov) and to be free of it. I am independent. ${ }^{2}$ My passions have again burnt out.

The next day, on August 1, Vygotsky travelled to the Thames to visit the Westminster Abbey and the Parliament. The austere buildings again left an unforgettable impression.

12 p.m. < ..> I ride to the Westminster and the Parliament. Today my heart again felt relieved somewhat, somehow more joyous.

1. 20 p.m. The Westminster Abbey. The soul is lost in the open, enormous and bleak spaces and is looking for something to grasp in order not to $<\ldots>$. G.

For all we know, this may have been the end of Vygotsky's sightseeing in London. There are no entries in his notebook for the next 2 days and the last note that can be hypothetically connected with Vygotsky's stay in London was made on Tuesday, August 4. What we know for sure is that on August 7, 1925, Vygotsky was back in Berlin, if we can rely on information provided by the Russian embassy (Rückriem 2008, p. 30). That could mean that Vygotsky left London for Vlissingen on the 5th, possibly stayed one night in the local luxurious Grand Hotel Des Bains, and then continued his journey by steam train through Holland on the 6th. His putative last day in London he spent reading:

10 p.m. I am reading $<\mathrm{G}>$. the whole day. The whole day. $<\ldots>$ Rose of my Jericho (my heather). How amazing $<\ldots>$ the reading fills me with calm, proud, despair. Rain all day.

Whom Vygotsky was reading during this day, letters by his wife G(okha), or a poet or novelist whose name also begins with G, say Nikolay Gumilyov, we will probably never know with certainty. It may even be that we read ' $G$ ' were it should be 'B'. In that case, Vygotsky was surely reading his favorite writer Ivan Bunin, who published a volume of short stories in Berlin in 1924 under the tile Rose of Jericho (Bunin 1984). Whatever interpretation we prefer, Vygotsky's exclamation "rose of my Jericho (my heather)!" is evocative. It was no doubt an allusion to the rose of Jericho or resurrection plant (Anastatica hierochuntica), a plant that can survive almost complete desiccation and revives in the rainy season. The reference to heather, which is not a first name in Russian, may have served the same function: to allude to the plant's ability to blossom after periods of drought. Both exclamations, then, may have been allusions to the ups and downs in Vygotsky's relationship with his wife Rosa (Rose).

Be that as it may, the final entry in Vygotsky's notebook can be dated Friday, August 21. It is a personal outcry that is characteristic of the notebook as a whole. Vygotsky writes:

The night after the letter. Aus Hotel Magdeburg. ${ }^{3}$ My Gokha. My golden birthday person. The first whole year of your life with me. At best we shall have no more than $20-30$ of these. It is horrifying to think-this is what I

\footnotetext{
2 "Independent" written like in English but in Cyrillic letters.

3 In German: "From Hotel Magdeburg".
} 
thought during the trip -20 days. And young and vigorous and courageous we may have only 5-10. And maybe at a certain moment it will come to an abrupt stop. Let it last until our very death.

\section{Conclusion}

The travelling, the many conference sessions to attend, the formal gatherings, and the frequent conversations with colleagues in foreign languages must have been fatiguing to Vygotsky. Moreover, foggish London cannot have been the ideal environment for a tuberculosis patient. Shortly after his return to Moscow, Vygotsky had a serious relapse and had to take to his bed. In a letter to Sherbina, dated October 28 , he wrote that he was ill and "lying in bed for 2 months now since I returned from abroad' (Rückriem 2008, p. 209). Later on, hospitalization proved necessary and Vygotsky spent more than half a year in the hospital Zakharino, where he underwent several operations, but he never fully recovered. In May 1926, 1 year after the London congress, he was temporarily acknowledged as an "invalid of the second group" (Vygodskaya and Lifanova 1996, pp. 94-95). Despite his serious illness, Vygotsky continued working and in the subsequent 9 years he accomplished the work for which he is now famous.

For Vygotsky the year 1925 was a year of transition. He had just entered the field of defectology after years of working in the world of theater and literature. The conference in London was the first and the last foreign conference he ever attended. From his notebook, he emerges as a very sensitive and spirited man who was constantly analyzing his own feelings and state of mind. Feelings of utter loneliness, depression and despair were followed by feelings of intense aesthetic enjoyment. Unhappiness about being forced to speak a foreign language and other obligations (wearing a suit, sitting at a banquet) was mixed with exalted ideas about the superiority of the Soviet view in science. His attitude in London was that of an observer of external events and of his own innermost feelings. In contradiction to what was believed before, Vygotsky never presented his ideas about deafness as a social defect to his foreign colleagues, nor did he play an active role during the congress. It remains unclear why the Soviet government sent a little known psychologist, who was only taking his first steps in the field of defectology, as its formal representative to a prestigious international congress. It remains equally unclear why the authorities financed a much longer stay than was necessary on strictly scientific grounds. The young, sensitive and brilliant Vygotsky may have profited from the London experience, although, to the best of our knowledge, in his subsequent defectological writings he never referred to any of the congress papers (cf. Vygotsky 1993). Presumably, his stay at the Psychological Institute in Berlin, which we hope to be able to reconstruct in the near future, was far more fruitful, both theoretically and in terms of scientific cooperation.

Open Access This article is distributed under the terms of the Creative Commons Attribution Noncommercial License which permits any noncommercial use, distribution, and reproduction in any medium, provided the original author(s) and source are credited. 


\section{References}

Akhmatova, A. (1977). Stikhotvoreniya (Poems). Moscow: Sovetskaya Rossiya.

Brill, R. G. (1984). International congresses on education of the deaf: An analytical history 1878-1980. Washington, DC: Gallaudet.

Bunin, I. A. (1984). Roza Ierikhona. In I. A. Bunin (Ed.), Izbrannye sochineniya (p. 284). Moscow: Khudozhestvennaya Literatura.

Goethe, W. (1975). Faust. München: Verlag C.H. Beck.

International conference on the education of the deaf (1925). London: W.H. Taylor \& Sons.

Khomskaya, E. D. (1992). Aleksandr Romanovich Luria: Nauchnaya biografiya (Alexander Romanovich Luria: Scientific biography). Moscow: Voenizdat.

Meshcheryakov, A. I. (1974). Slepoglukhonemye deti (Blind deafmute children). Moscow: Pedagogika.

Muhs, S. (2002). Deaf people as eyewitnesses of national socialism. In D. F. Ryan \& J. S. Schuchman (Eds.), Deaf people in Hitler's Europe (pp. 78-97). Washington: Gallaudet University Press.

Rückriem, G. (2008). Lev Semënovič Vygotskij. Briefe/Letters. 1924-1934. Berlin: Lehmanns Media.

Valsiner, J., \& Van der Veer, R. (2000). The social mind. Cambridge: Cambridge University Press.

Van der Veer, R. (2000). Tamara Dembo's early years: Working with Lewin and Buytendijk. Journal of the History of the Behavioral Sciences, 36, 109-126.

Van der Veer, R. (2007). Lev Vygotsky. London: Continuum.

Van der Veer, R. (2008). Einleitung/Introduction. In G. Rückriem (Ed.), Lev Semënovič. Vygotskij: Briefel Letters. 1924-1934 (pp. 13-18; 189-193). Berlin: Lehmann's Media.

Van der Veer, R., \& Valsiner, J. (1991). Understanding Vygotsky: A quest for synthesis. Oxford: Basil Blackwell.

Van der Veer, R., \& Valsiner, J. (Eds.). (1994). The Vygotsky Reader. Oxford: Basil Blackwell.

Vygotsky, L. S. (Ed.). (1924a). Voprosy vospitaniya slepykh, glukhonemykh i umstvenno otstalykh detey (Problems of the education of blind, deafmute and mentally retarded children). Moscow: Izdatel'stvo SPON NKP.

Vygotsky, L. S. (1924b). K psikhologii I pedagogike detskoy defektivnosti. In L. S. Vygotsky (Ed.), Voprosy vospitaniya slepykh, glukhonemykh i umstvenno otstalykh detey (Problems of the education of blind, deafmute and mentally retarded children) (pp. 5-30). Moscow: Izdatel'stvo SPON NKP.

Vygotsky, L. S. (1924c). Predislovie (Foreword). In L. S. Vygotsky (Ed.), Voprosy vospitaniya slepykh, glukhonemykh $i$ umstvenno otstalykh detey (Problems of the education of blind, deafmute and mentally retarded children) (pp. 3-4). Moscow: Izdatel'stvo SPON NKP.

Vygotsky, L. S. (1925a). Soznanie kak problema psikhologiya povedeniya (Consciousness as a problem for behaviorism). In Kornilov (Ed.), Psikhologiya i marksizm (pp. 175-198). Moscow: Gosudarstvennoe Izdatel'stvo.

Vygotsky, L. S. (1925b). Predislovie (Foreword). In S. Freud (Ed.), Po tu storonu printsipa udovol'stviya (pp. 3-16). Moscow: Sovremennye Problemy.

Vygotsky, L. S. (1925c). Predislovie (Foreword). In A. F. Lazursky (Ed.), Psikhologiya obshchaya I eksperimental'naya (pp. 5-23). Leningrad: Gosudarstvennoe Izdatel'stvo.

Vygotsky, L. S. (1925d). Printsipy vospitaniya fizicheski defektivnykh detej (Principles of the education of physically defective children). Narodnoe Prosveshchenie, 1, 112-120.

Vygotsky, L. S. (1925e). O vspomogatel'noy shkole (About the special school). Review of A.N. Graborov, Vspomagatel'naya shkola. Narodnoe Prosveshchenie, 9, 170-171.

Vygotsky, L. S. (1925f). Principles of social education for deaf and dumb children in Russia. In International Conference on the Education of the Deaf (pp. 227-235). London: Taylor \& Sons.

Vygotsky, L. S. (1926/1997). The historical meaning of the crisis in psychology: A methodological investigation. In R. W. Rieber \& J. Wollock (Eds.), The collected works of L.S. Vygotsky. Vol. 3. Problems of the theory and history of psychology (pp. 233-343). New York: Plenum.

Vygotsky, L. S. (1993). The collected works of L.S. Vygotsky. Vol. 2. The fundamentals of defectology. New York: Plenum.

Vygodskaya, G. L., \& Lifanova, T. (1996). Lev Semenovich Vygotskyj: Zhizn, deyatel'nost', shtrikhi $k$ portretu. Moscow: Smysl.

Wilson, A. N. (1988). Tolstoy. New York: Fawcett Columbine. 
René van der Veer is Casimir professor of the history of education at Leiden University, The Netherlands. He published widely on the history of developmental psychology and pediatrics. Among his books are Understanding Vygotsky (with Valsiner, 1991), The Social Mind (with Valsiner, 2000), Lev Vygotsky (2007), and Opvoeden door Beginners (2011).

Ekaterina Zavershneva (PhD) is associate professor of psychology at the Department of Clinical Psychology of Moscow State University of Medical Den stry. Her main research interests are methodology and philosophy of science, history of psychology, and Vygotskian theory. She recently published and will con nue to publish on materials found in the Vygodsky family archives in such journals as Journal of Russian and East European Psychology, Voprosy Psikhologii, and Novoe Literaturnoe Obozrenie. 